A RCHIWA, BIBLIOTEKI

I MUZEA KOŚCIELNE 110 (2018)

https://doi.org/10.31743/abmk.2018.110.18

ROBERT STĘPIEN'* - LUBLIN

\title{
LOSY BENEDYKTYNÓW SIECIECHOWSKICH PO KASACIE OPACTWA W 1819 ROKU
}

Dzieje zakonników przebywających w znoszonych domach zakonnych były już przedmiotem badań prowadzonych nad problematyką kasat i losów poklasztornego dziedzictwa kulturowego. Podstawowe znaczenia w tym zakresie mają prace Piotra Pawła Gacha, ukazujące kontekst prawno-polityczny, wymiar ilościowy i zasięg terytorialny procesu supresji zakonnej ${ }^{1}$, oraz publikacje wydane w ramach projektu, mającego na celu zinwentaryzowanie i opracowanie spuścizny materialno-duchowej, pozostałej po klasztorach skasowanych na ziemiach dawnej Rzeczypospolitej i na Śląsku w XVIII i XIX w. ${ }^{2}$ Pokasacyjne losy ostatnich zakonników konwentu sieciechowskiego nie cieszyły się dotąd zainteresowaniem

* Robert Stępień - dr historii; adiunkt w Instytucie Historii; Uniwersytet Marii CurieSkłodowskiej w Lublinie; e-mail: robertstepien86@gmail.com

ORCID 0000-0003-3453-4185

${ }^{1}$ P.P. Gach, Zakony w diecezji kieleckiej 1805-1914, „Nasza Przeszłość”, 59 (1983) s. 165-213; tenże, Kasaty zakonów na ziemiach dawnej Rzeczypospolitej i Śląsa: 1773-1914, Lublin 1984; tenże, Struktura i działalność duszpasterska zakonów męskich na ziemiach dawnej Rzeczypospolitej i Ślaska w latach 1773-1914, Lublin 1999.

${ }^{2} \mathrm{~W}$ zakresie interesującej nas problematyki należy wymienić m.in. prace: W. Rosowski, Losy zakonników z klasztorów rzymskokatolickich na Ukrainie Prawobrzeżnej skasowanych w XIX w., w: Kasaty klasztorów na obszarze dawnej Rzeczypospolitej Obojga Narodów i na Ślasku na tle procesów sekularyzacyjnych w Europie, t. 1, Geneza. Kasaty na ziemiach zaborów austriackiego i rosyjskiego, red. M. Derwich, Wrocław 2014, s. 287-301; H. Gerlic, Rewerenda zamiast mniszego habitu - cystersi ślascy po kasacie ich opactw, w: Kasaty klasztorów na obszarze dawnej Rzeczypospolitej Obojga Narodów i na Śląsku na tle procesów sekularyzacyjnych $w$ Europie, t. 2, Kasaty na Ślasku Pruskim i na ziemiach zaboru pruskiego, red. M. Derwich, Wrocław 2014, s. 165-186; W. Zawadzki, Losy franciszkanów w Prusach Zachodnich w okresie kasat ich klasztorów, „Hereditas Monasteriorum", 2 (2013) s. 95-107. Biogramy ostatnich zakonników skasowanych klasztorów zostały częściowo opracowane w ramach internetowego portalu wiedzy na stronie: www.kasaty.pl. Z innych prac warto przywołać: M. Kanior, Końcowe dzieje Polskiej Kongregacji Benedyktyńskiej Św. Krzyża (1772-1864), „Analecta Cracoviensia”, 14 (1982) s. 557-609; tenże, Polska Kongregacja Benedyktyńska Świętego Krzyża: 1709-1864, Kraków 2000; R. Prejs, Stownik biograficzny zakonników franciszkańskich Królestwa Polskiego po kasacie 1864 r., Poznań 2004. 
badaczy tematyki kasat klasztornych. Podobnie historia klasztoru w Sieciechowie nie doczekała się zbyt wielu opracowań naukowych. Jedyną monografią dziejów opactwa sieciechowskiego pozostaje praca ks. Józefa Gackiego, wydana drukiem w $1872 \mathrm{r}^{3}$ Wiele cennych informacji dla swojego dzieła autor ten pozyskał od żyjących ówcześnie byłych członków zgromadzenia sieciechowskiego. W latach 50. XX w. badania nad rozwojem posiadłości ziemskich opactwa oraz nad najstarszym dokumentem sieciechowskim prowadził Eugeniusz Wiśniowski ${ }^{4}$. Późniejsze studia nad klasztorem koncentrowały się na tematyce związanej m.in. z jego fundacją ${ }^{5}$, sprawami prawno-majątkowymi ${ }^{6}$, dziejami i charakterystyką spuścizny bibliotecznej ${ }^{7}$, przebiegiem kasaty ${ }^{8}$ oraz architekturą kościoła pobenedyktyńskiego ${ }^{9}$. W ostatnich latach, po przeszło półwieczu, wznowiono badania archeologiczne w pobliżu zabudowań dawnego klasztoru, których wyniki mogą rzucić nowe światło na problem jego fundacji ${ }^{10}$.

${ }^{3}$ J. Gacki, Benedyktyński klasztor w Sieciechowie wedlug pism i podań miejscowych, Radom 1872. Zob. też: W. Pestka, Jak mało ... ks. Józef Gacki (1805-1876) - zarys biografii, Radom 2012.

${ }^{4}$ E. Wiśniowski, $Z$ dziejów opactwa benedyktynów w Sieciechowie (XIII-XVI w.), ,Roczniki Humanistyczne", 7 (1958) z. 2, s. 23-120; tenże, Najstarszy dokument benedyktynów sieciechowskich (1252), „Studia Źródłoznawcze”, 4 (1959) s. 57-73.

${ }^{5}$ M. Derwich, Monastycyzm benedyktyński w średniowiecznej Europie i Polsce. Wybrane problemy, Wrocław 1998, s. 194-195; J. Dobosz, Monarchia i możni wobec Kościoła w Polsce do początku XIII wieku, Poznań 2002, s. 257-260.

${ }^{6}$ A. Szymanek, Pożyczka benedyktynów z Sieciechowa dla Żydów ze Zwolenia i Janowca, 1685 r., „Notatnik Janowiecki”, 16 (2009) s. 355-363; R. Stępień Spory o granice posiadłości ziemskich benedyktynów z Sieciechowa, „Słupskie Studia Historyczne”, 18 (2012) s. 61-70.

${ }^{7}$ M. Juda, Kultura książki w kręgu benedyktynów. Na marginesie dziejów opactwa w Sieciechowie, „Przegląd Informacyjno-Dokumentacyjny”, 2 (2005) s. 45-64; J. Kaliszuk, Codices deperditi. Średniowieczne rękopisy tacińskie Biblioteki Narodowej utracone w czasie II wojny światowej, t. 1, Dzieje i charakterystyka kolekcji, Wrocław 2016, s. 284-294.

${ }^{8}$ F.T. Borowski, Dekret kasacyjny z roku 1819 i jego wykonanie w stosunku do zakonów diecezji sandomierskiej, „Studia Sandomierskie”, 18 (2011) nr 1, s. 99-112; K. Stalmach, Administracja lasów suprymowanych $i$ duchownych województwa sandomierskiego w latach 1818-1832, „Ziemia Kozienicka”, 24-25 (2011) s. 5-22; K. Stalmach, Kasata zakonu benedyktynów sieciechowskich w 1819 r. i zarzad ich majątku w okresie konstytucyjnym, (mps, praca doktorska obroniona w 2008 r. na Katolickim Uniwersytecie Lubelskim).

${ }^{9} \mathrm{M}$. Brykowska, W sprawie architektury zespołu pobenedyktyńskiego w Opactwie-Sieciechowie, „Kwartalnik Architektury i Urbanistyki”, 15 (1970) z. 2, s. 203-211; D. Miszczak, Późnobarokowy kościót pobenedyktyński w Sieciechowie-Opactwie, „Rocznik Muzeum Świętokrzyskiego”, 9 (1975) s. 367-383; W. Zdon, Światynia jako miejsce na granicy przemijania i wiecznej szczęśliwości, czyli o znaczeniu campanulli $w$ architekturze kościoła opackiego w Sieciechowie, w: Obraz i przyroda, red. M. Mazurczak, J. Patyra, M. Żak, Lublin 2005, s. 549-559; W. Zdon, Dydaktyka zbawienia na sklepieniach pobenedyktyńskiego kościoła w opactwie sieciechowskim, „Arteria. Rocznik Katedry Sztuki Wydziału Nauczycielskiego Politechniki Radomskiej”, 6 (2008) s. 33-38.

${ }^{10} \mathrm{~T}$. Wąsowicz, Topografia wczesnośredniowiecznego Sieciechowa, „Przegląd Historyczny”, 50 (1959) z. 3, s. 569-581; E. Kowalczyk, Powracajacy temat Sieciechów. Z problemów organizacji grodowej w Polsce wczesnośredniowiecznej, „Kwartalnik Historii Kultury Materialnej”, 42 (1994) z. 1, s. 69-85; Z. Lechowicz, P. Filipowicz, Stan badań nad średniowiecznym opactwem w Sieciechowie, w: Radom: korzenia miasta i regionu, t. 4, Ziemia niczyja - ziemia nieznana. 
Rekonstrukcja losów ostatnich zakonników sieciechowskich, ale też części zbiorów zachowanego dziedzictwa poklasztornego ${ }^{11}$, służy zainicjowaniu procesu mającego na celu przywrócenie klasztorowi w Sieciechowie adekwatnej do jego rangi pozycji w historiografii, tak aby zaczął na nowo ukazywać swą dawną wielkość oraz rolę, jaką odgrywał w społeczeństwie, państwie i Kościele czasów średniowiecza, a także w okresie nowożytnym. Zamysł ten nabiera szczególnego znaczenia w kontekście zbliżającej się dwusetnej rocznicy kasaty opactwa w $1819 \mathrm{r}$. Podstawowym materiałem źródłowym dla poniższych ustaleń były teczki personalne duchowieństwa oraz akta konduit i stanu służby kapłanów przechowywane w zasobie Archiwum Diecezjalnego w Sandomierzu ${ }^{12}$. Pomocne na wstępnym etapie badań okazały się prace ks. Jana Wiśniewskiego, opisujące dekanaty i parafie położone $\mathrm{w}$ granicach dawnej diecezji sandomierskiej. Biogramy kilku zakonników sieciechowskich zostały częściowo opracowane w ramach Słownika biograficznego księży diecezji sandomierskiej ${ }^{13}$. Dla potrzeb weryfikacji i uzupełnienia informacji tam zawartych wykorzystano schematyzmy diecezjalne, księgi metrykalne i akta stanu cywilnego oraz dokumentację poszczególnych parafii, w których swoją posługę sprawowali zakonnicy sieciechowscy. Zasadnicze znaczenie dla ustalenia składu personalnego klasztoru w okresie kasaty miały akta urzędowe okupacji i ewakuacji suprymowanego opactwa, przechowywane w Archiwum Państwowym w Radomiu oraz w Archiwum Głównym Akt Dawnych w Warszawie ${ }^{14}$.

Dekret supresyjny, wydany w imieniu prymasa Franciszka Skarbka-Malczewskiego 17 kwietnia 1819 r., umieścił klasztor sieciechowski w grupie domów zakonnych przeznaczonych do całkowitej likwidacji ${ }^{15}$. Komisarze delegowani do okupacji opactwa, Andrzej Witkowski, sędzia pokoju powiatu kozienickiego, oraz ks. Tomasz Korycki, dziekan zwoleński i proboszcz parafii w Suchej, przybyli do Sieciechowa 11 czerwca 1819 r. W kolejnych dniach pobytu w klasztorze komisarze przygotowali dokładny opis stanu klasztornych funduszy, źródeł dochodów, wydatków, długów i ciężarów gruntowych, zabudowań klasztornych oraz majątku

Schylek starożytności i średniowiecze na ziemiach między Wista a Pilica, red. A. Buko, D. Główka, M. Trzecieski, Warszawa 2013, s. 193-222; Ł. Reczulski, Wójtowa Góra w Sieciechowie, „Acta Universitatis Lodziensis. Folia Archaeologica”, 30 (2015) s. 187-205.

${ }^{11}$ R. Stępień, Pokasacyjne losy i obecny stan zachowania archiwaliów klasztoru Benedyktynów z Sieciechowa, „Res Historica”, 45 (2018) s. 131-153.

${ }^{12}$ Składam serdeczne podziękowania dla ks. Emila Hapaka za pomoc okazaną podczas korzystania z materiałów archiwalnych przechowywanych w zasobie Archiwum Diecezjalnego w Sandomierzu.

${ }^{13}$ B. Stanaszek, R. Nowakowski, P. Tylec, Stownik biograficzny księży diecezji sandomierskiej $X I X-X X$ w. t. 1-3, Sandomierz 2014-2017.

${ }^{14}$ Archiwum Państwowe w Radomiu (dalej: APR), Zarząd Rolnictwa i Dóbr Państwowych Guberni Radomskiej, Kieleckiej, Lubelskiej i Siedleckiej (dalej: ZDP), Sukcesje, sygn. 1225, 1226; Archiwum Główne Akt Dawnych (dalej: AGAD), Centralne Władze Wyznaniowe Królestwa Polskiego (dalej: CWWKP), sygn. 796, 797.

${ }^{15}$ AGAD, CWWKP, sygn. 177, s. 157-159 (thumaczenie dekretu na j. polski - wyciąg); AGAD, CWWKP, sygn. 178, s. 30-36 (kopia dekretu w j. łacińskim); M. Kośka, Dekret abpa Franciszka Skarbka-Malczewskiego z 17 IV 1819 r. w sprawie supresji klasztorów w Królestwie Polskim, „Hereditas Monasteriorum”, 8 (2016) s. 367-378. 
ruchomego. Lista osób tworzących zgromadzenie sieciechowskie, ujęta w protokole okupacyjnym opactwa z dnia 30 czerwca 1819 r., wymienia nazwiska 22 zakonników, z których 15 posiadało święcenia kapłańskie, a 7 pozostałych było klerykami, nowicjuszami lub braćmi laikami ${ }^{16}$.

Zdecydowana większość benedyktynów sieciechowskich pochodziła z terenu Królestwa Polskiego. Pojedynczy zakonnicy przybyli do klasztoru z Francji, Galicji i ze Śląska Pruskiego. W czasie spisywania protokołu czterech mnichów nie rezydowało na stałe w klasztorze. Trzech znajdowało się na placówkach parafialnych w charakterze proboszczów i wikariuszy, a jeden pełnił posługę kapelana wojskowego. Średni wiek zakonników sieciechowskich oscylował wówczas wokół granicy 40 lat. Ośmiu mnichów nie ukończyło jeszcze 30 lat, a wśród nich pięciu miało 21 bądź 22 lata. Odsetek młodych ludzi wskazuje na stały rozwój stanu osobowego zgromadzenia i poniekąd dowodzi, że klasztor w tamtym okresie funkcjonował normalnie i raczej nie zakończyłby swojego istnienia naturalną śmiercią ${ }^{17}$. Należy zauważyć, że skład konwentu klasztornego podlegał ciągłej zmianie, o czym świadczą zachowane listy zakonników z okresu przedkasacyjnego oraz data wstąpienia części z nich do klasztoru ${ }^{18}$.

Tabela 1. Lista osób tworzących zgromadzenie klasztoru sieciechowskiego w dniu 30 czerwca 1819 r.

\begin{tabular}{|c|c|c|c|c|}
\hline $\begin{array}{c}\text { Imię i nazwisko } \\
\text { zakonnika }\end{array}$ & $\begin{array}{c}\text { Urząd } \\
\text { klasztorny }\end{array}$ & Wiek & $\begin{array}{c}\text { Data wstąpienia } \\
\text { do klasztoru } \\
\text { sieciechowskiego }\end{array}$ & $\begin{array}{c}\text { Czas i miejsce } \\
\text { odbycia nowicjatu }\end{array}$ \\
\hline $\mathbf{1}$ & $\mathbf{2}$ & $\mathbf{3}$ & $\mathbf{4}$ & $\mathbf{5}$ \\
\hline $\begin{array}{c}\text { Wojciech } \\
\text { Biedrzycki }\end{array}$ & opat & 46 & 6 V 1791 & $\begin{array}{c}8 \text { IX } 1796 \\
\text { Sieciechów }\end{array}$ \\
\hline Hipolit Kurosz & przeor & 43 & 27 IV 1790 & $\begin{array}{c}6 \text { V } 1799 \\
\text { Sieciechów }\end{array}$ \\
\hline
\end{tabular}

${ }^{16}$ APR, ZDP, Sukcesje, sygn. 1225, k. 39r-40r, Lista imienna osób składających zgromadzenie męskie klasztoru sieciechowskiego XX benedyktynów, ułożona dnia 30 miesiąca czerwca 1819 roku; J. Gacki, Benedyktyński klasztor w Sieciechowie, s. 147. Dla porównania klasztor świętokrzyski w okresie kasaty liczył 27 członków, w tym 18 kapłanów, 7 kleryków i 2 braci. Zob. APR, ZDP, Sukcesje, sygn. 1456, k. 16r-17r; Gacki, Benedyktyński klasztor Świętego Krzyża na tysej Górze, Warszawa 1873, s. 132-133; P.P. Gach, Opactwo i sanktuarium Świętego Krzyża w epoce kasat zakonnych (XVIII-XIX wiek), w: Klasztor na Świętym Krzyżu w polskiej kulturze narodowej, red. D. Olszewski, R. Gryz, Kielce 2000, s. 154.

${ }^{17}$ Borowski, Dekret kasacyjny, s. 106-107.

${ }^{18}$ AGAD, CWWKP, sygn. 796, s. 25-26. Lista zakonników sieciechowskich z 1818 r. w porównaniu z wykazem z 1819 r. dodatkowo wymienia Jana Gwalberta Kołaczyńskiego, doktora teologii, oraz Hieronima Pękowskiego, studenta filozofii. Brakuje jednak na niej Leandra Herczewicza i Tomasza Orzechowskiego, obecnych w wykazie protokołu okupacyjnego klasztoru. Wśród zakonników, którzy odbyli w latach wcześniejszych nowicjat w Sieciechowie i przeżyli okres kasaty opactwa, byli m.in. Antoni Zwoleński, Piotr Kazimierz Palczewski, Jan Grzywaczewski i Ludwik Czepkowski. Zob. Archiwum Diecezjalne w Sandomierzu (dalej: ADS), Akta konduit. Stan służby kapłanów 1835, nr 36, 268; Słownik biograficzny księży, t. 1, s. 269; Tamże, t. 3, s. 136-137. 


\begin{tabular}{|c|c|c|c|c|}
\hline 1 & 2 & 3 & 4 & 5 \\
\hline Wacław Kowiński & podprzeor & 58 & $16 \times 1781$ & $\begin{array}{c}8 \text { III } 1788 \\
\text { Sieciechów }\end{array}$ \\
\hline Emilian Wąsicki & dziekan jubilat & 76 & 20 XI 1767 & $\begin{array}{c}3 \text { V } 1770 \\
\text { Sieciechów }\end{array}$ \\
\hline $\begin{array}{c}\text { Leander } \\
\text { Herczewicz }\end{array}$ & depozytarz & 58 & 13 VIII 1779 & $\begin{array}{l}24 \text { X } 1785 \\
\text { Sieciechów }\end{array}$ \\
\hline Paweł Maicki & $\begin{array}{l}\text { na parafii w } \\
\text { Brzeźnicy }\end{array}$ & 43 & 13 VIII 1797 & $\begin{array}{c}\text { 3 V } 1806 \\
\text { Sieciechów }\end{array}$ \\
\hline Beda Lipowski & profesor szkół & 43 & 31 VII 1799 & $\begin{array}{c}3 \text { V } 1803 \\
\text { Sieciechów }\end{array}$ \\
\hline $\begin{array}{c}\text { Bernard } \\
\text { Dutkowski }\end{array}$ & kapelan w wojsku & 39 & $5 \times 1802$ & $\begin{array}{c}3 \text { V } 1806 \\
\text { Sieciechów }\end{array}$ \\
\hline $\begin{array}{l}\text { Kolumban } \\
\text { Jastrzębski }\end{array}$ & prowizor & 39 & $5 \times 1802$ & $\begin{array}{l}19 \text { XII } 1808 \\
\text { Sieciechów }\end{array}$ \\
\hline $\begin{array}{c}\text { Augustyn } \\
\text { Kędzierski }\end{array}$ & $\begin{array}{c}\text { na parafii } \\
\text { w Rakowie }\end{array}$ & 34 & 12 XI 1808 & $\begin{array}{l}29 \text { XI } 1813 \\
\text { Sieciechów }\end{array}$ \\
\hline Antoni Kowalski & vice rektor szkół & 35 & 3 III 1808 & $\begin{array}{l}29 \text { XI } 1813 \\
\text { Sieciechów }\end{array}$ \\
\hline $\begin{array}{c}\text { Hilary } \\
\text { Kasperowicz }\end{array}$ & $\begin{array}{c}\text { na parafii } \\
\text { w Rakowie }\end{array}$ & 29 & 19 I 1811 & $\begin{array}{c}3 \mathrm{~V} 1814 \\
\text { Sieciechów }\end{array}$ \\
\hline $\begin{array}{c}\text { Izydor } \\
\text { Makowiecki }\end{array}$ & chórzysta & 27 & $23 \mathrm{~V} 1815$ & $\begin{array}{l}8 \text { XII } 1817 \\
\text { Sieciechów }\end{array}$ \\
\hline Kajetan Strasz & chórzysta & 29 & 14 VII 1815 & $\begin{array}{l}8 \text { XII } 1817 \\
\text { Sieciechów }\end{array}$ \\
\hline Emilian Febuerier & chórzysta & 53 & 14 IX 1817 & $\begin{array}{c}6 \text { XI } 1790 \\
\text { Francja }\end{array}$ \\
\hline $\begin{array}{l}\text { Kazimierz } \\
\text { Lipowski }\end{array}$ & chórzysta & 22 & $23 \mathrm{~V} 1815$ & - \\
\hline Adam Staszewski & profesor szkół & 21 & $23 \mathrm{~V} 1815$ & - \\
\hline $\begin{array}{c}\text { Laurenty } \\
\text { Brekowski }\end{array}$ & nowicjusz & 22 & 3 VIII 1816 & - \\
\hline Idzi Siennicki & nowicjusz & 22 & 3 VIII 1816 & - \\
\hline Placyd Orłowski & nowicjusz & 21 & 14 VII 1815 & - \\
\hline $\begin{array}{l}\text { Bonifacy } \\
\text { Trylinger }\end{array}$ & - & 74 & 14 VII 1814 & - \\
\hline $\begin{array}{c}\text { Tomasz } \\
\text { Orzechowski }\end{array}$ & nowicjusz & 58 & 24 XII 1817 & - \\
\hline
\end{tabular}

Źródło: APR, ZDP, Sukcesje, sygn. 1225, k. 39r-40r; AGAD, CWWKP, sygn. 797, s. 28-29.

Komisarze delegowani do ewakuacji klasztoru sieciechowskiego, Edward Watson, komisarz obwodu radomskiego, oraz ks. Wojciech Grzegorzewski, pleban zwoleński, 2 sierpnia 1820 r. poinformowali zakonników, że na mieszkanie dla benedyktynów z obszaru Królestwa Polskiego, zgodnie z decyzją Deputacji Spraw Zniesionych Instytutów Duchownych (Deputacja SZID), wyznaczono 
dwa klasztory: w Sieciechowie i Pułtusku ${ }^{19}$. Przeor sieciechowski Hipolit Kurosz $\mathrm{w}$ imieniu całego zgromadzenia odmówił pozostania w klasztorze, decyzję tę argumentując zbyt niską kompetencją przyznaną zakonnikom, którym, jak nadmienił, odebrano całe uposażenie materialne i poddanych, a budynki gospodarcze oddano w dzierżawę. Podał przy tym listę dwunastu służących, niezbędnych w jego opinii, dla dalszego ewentualnego pobytu mnichów w Sieciechowie, którym należałoby przyznać pensję, zapewnić mieszkanie i wyżywienie. Komisarze, mimo oświadczenia przełożonego klasztoru, wezwali z osobna każdego z zakonników do złożenia deklaracji odnośnie dalszych planów na przyszłość, od czego uzależniono przyznanie im rocznej renty ${ }^{20}$. Deklarację złożyło tylko siedemnastu zakonników, w tym za czterech nieobecnych, a przebywających na parafiach lub w wojsku, uczynili to współbracia. Poza Sieciechowem w tym czasie znajdowali się już trzej nowicjusze, którzy opuścili klasztor po zakończeniu okupacji opactwa, nie czekając na dalsze etapy kasaty. Opat sieciechowski, Wojciech Biedrzycki, oznajmił, że mimo pragnienia pozostania w klasztorze, zmuszony jest przenieść się do wioski, którą otrzymał w dożywotnią dzierżawę. Pozostali zakonnicy w większości deklarowali zamiar powrotu do rodziny bądź pozostania na placówkach parafialnych, w których pełnili już posługę duszpasterską. Tylko dwóch zakonników wyraziło życzenie umieszczenia w którymś z zachowanych klasztorów benedyktyńskich. Jeden schorowany mnich prosił o przeniesienie do klasztoru bonifratrów. Klerycy i nowicjusze pragnęli kontynuowania studiów $\mathrm{w}$ seminarium duchownym, a następnie włączenia w szeregi duchowieństwa świeckiego ${ }^{21}$.

Zapytania władz państwowych i kościelnych kierowane do H. Kurosza w kilka lat po kasacie opactwa, z prośbą o wskazanie miejsca pobytu niektórych jego współbraci, dowodzą, że zakonnicy sieciechowscy w tamtym czasie rozproszyli się po różnych parafiach, rozmieszczonych na terenie kilku ówcześnie istniejących diecezji. W styczniu $1821 \mathrm{r}$. H. Kurosz informował biskupa sandomierskiego, że miejscowi benedyktyni, nie mogąc utrzymać się w klasztorze, rozjechali się do różnych miejsc, oraz, że nikt nowy z innych ośrodków klasztornych nie przybył do Sieciechowa. Już w sierpniu 1821 r. nie było wiadomo, gdzie aktualnie znajduje się część zakonników sieciechowskich. Komisja Rządowa Wyznań Religijnych i Oświecenia Publicznego (KRWRiOP) w piśmie do biskupa sandomierskiego prosiła o wskazanie miejsca pobytu niektórych z nich. W tym czasie w Sieciechowie, według wyjaśnień $\mathrm{H}$. Kurosza, przebywało dwóch mnichów,

${ }_{19}$ ADS, Akta zakonne różne (1820-1824), brak paginacji (b.p.), Pismo Deputacji Spraw Zniesionych Instytutów Duchownych do Biskupa Sandomierskiego, Warszawa 16 VI 1820; APR, ZDP, Sukcesje, sygn. 1226, k. 104r-104v.

${ }^{20}$ Komisarze ułożyli listę 15 zakonników posiadających prawo do pobierania kompetencji. Decyzją Komisji Województwa Sandomierskiego roczną pensję przyznano jednak mniejszej liczbie osób. Pierwszą pensję benedyktyni otrzymali dopiero w grudniu $1820 \mathrm{r}$. Zakonnicy zatrudnieni na parafiach i w wojsku nie pobierali kompetencji z funduszu religijnego. Por. APR, ZDP, Sukcesje, sygn. 1226, k. 107r-108r; Borowski, Dekret kasacyjny, s. 106-107.

${ }^{21}$ APR, ZDP, Sukcesje, sygn. 1226, 104r-106v; Consignatio Cleri Saecularis ac Regularis Dioecesis Sandomiriensis pro Anno 1820 Confecta, s. 85; Borowski, Dekret kasacyjny, s. 107. 
pozostali zaś poszli na kapelanie i posługę parafialnąa 22 O tym, jak różne były losy benedyktynów sieciechowskich po kasacie opactwa, informują zamieszczone biogramy zakonników, które w swym założeniu stanowią punkt wyjścia do dalszych badań nad dziejami benedyktynów z Sieciechowa, jak też szerzej nad problematyką losów duchowieństwa zakonnego w okresie XIX-wiecznych kasat klasztornych.

\section{$* * *$}

Ostatni opat klasztoru sieciechowskiego, Wojciech Biedrzycki, urodził się w 1773 r. we wsi Biedrzyce w dawnym powiecie pułtuskim, w ziemi różańskiej $^{23}$. Na chrzcie św. otrzymał imię Jakub. W 1791 r. dołączył do konwentu benedyktynów w Sieciechowie, gdzie w 1796 r. ukończył nowicjat. W dniu 18 lipca 1814 r. został wybrany opatem klasztoru, wcześniej pełniąc funkcję przeora zgromadzenia sieciechowskiego ${ }^{24}$. Po kasacie opactwa w 1819 r. przeniósł się do folwarku Słowiki, wchodzącego w skład dóbr opackich ${ }^{25}$, który otrzymał w dożywocie jako kompetencję roczną wynoszącą 6.000 złp. Zmarł w Słowikach 27 października $1824 \mathrm{r}$. w wieku 51 lat $^{26}$. W aktach notariusza kozienickiego Filipa Wroczyńskiego zachował się spis masy spadkowej, poddanej publicznej licytacji, zawierającej rzeczy osobiste zakonnika, wykazy sprzętów domowych i gospodarskich oraz katalog księgozbioru prywatnej biblioteki ${ }^{27}$.

Ostatni przeor klasztoru, Hipolit Kurosz, do konwentu sieciechowskiego dołączył w 1790 r., a w 1799 r. przyjął święcenia kapłańskie ${ }^{28}$. Był profesorem teologii, prefektem i nauczycielem szkoły przyklasztornej, administratorem kościołów w Brzeźnicy i Sieciechowie. Dwukrotnie sprawował funkcję przeora klasztoru,

${ }^{22}$ ADS, Akta zakonne różne (1820-1824), b.p., List przeora H. Kurosza do konsystorza generalnego diecezji sandomierskiej, Sieciechów 5 IX 1821; ADS, Akta benedyktyni Sieciechów 18041823 , s. 620-623, 628-632.

${ }^{23}$ APR, Urząd Stanu Cywilnego Parafii Rzymskokatolickiej Brzeźnica, sygn. 13, s. 112, nr 48.

${ }^{24} \mathrm{~W}$ dniu 30 sierpnia 1814 r. uzyskał oficjalną nominację Stolicy Apostolskiej na urząd opata sieciechowskiego. Zob. ADS, Akta benedyktyni Sieciechów 1804-1823, s. 645; Gacki, Benedyktyński klasztor w Sieciechowie, s. 228.

${ }^{25}$ APR, ZDP, Sukcesje, sygn. 1253, Akta lustracji folwarku Słowiki ze wsiami zarobnemi Brzeźnica, Mozolice i Słowiki dawniej opactwa klasztornego XX Benedyktynów Sieciechowskich, 1819-1825.

${ }^{26}$ APR, Urząd Stanu Cywilnego Parafii Rzymskokatolickiej Brzeźnica, sygn. 13, s. 112, nr 48. J. Gacki podał, że W. Biedrzycki zmarł w 1825 r., a za nim informację o dacie śmierci ostatniego opata sieciechowskiego powielano w kolejnych pracach. Por. Gacki, Benedyktyński klasztor w Sieciechowie, s. 228.

${ }^{27}$ K. Jaroszek, Inwentarz pozostałości po ostatnim opacie sieciechowskim ks. Wojciechu Biedrzyckim z 1824 r., „Biuletyn Kwartalny Radomskiego Towarzystwa Naukowego”, 33 (1998) z. 2-4, s. 125-142.

${ }^{28} \mathrm{~W}$ aktach pojawiają się różne daty i miejsca urodzenia ks. Kurosza - 1774 r. i 1775 r. oraz miejscowości Wielgie i Jasienice. Podobne rozbieżności dotyczą czasu wstąpienia do klasztoru sieciechowskiego - 1790 r. i 1793 r. Por. APR, ZDP, Sukcesje, sygn. 1225, k. 39v; ADS, Akta konduit. Stan służby kapłanów 1835, t. 1, nr 125 (a za nimi: Stownik biograficzny księży, t. 2, s. 179). 
będąc wybranym na ten urząd w 1805 i 1817 r. ${ }^{29}$ Po kasacie opactwa przez okres niemal 20 lat pozostawał proboszczem parafii w Sieciechowie ${ }^{30}$, gdzie zmarł 9

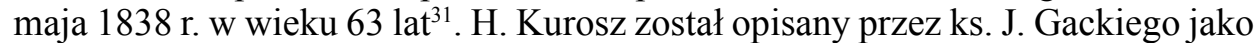
człowiek niepospolitych zdolności, grający na kilku instrumentach muzycznych, z łatwością mówiący w językach obcych, znakomity kaznodzieja i śpiewak pieśni kościelnych ${ }^{32}$. Zachowane akta klasztorne dowodzą, że H. Kurosz wyróżniał się na tle innych zakonników tworzących konwent sieciechowski pod względem zdolności intelektualnych i organizacyjnych. Był jednak osobą, która wzbudzała spore kontrowersje w otaczającej go wspólnocie zakonnej oraz w społeczności parafialnej, w zakresie działań podejmowanych jako przełożony klasztoru i proboszcz sieciechowski. Świadczą o tym akta kościelne, dotyczące postępowania wyjaśniającego, wobec stawianych mu licznych zarzutów o niegospodarność w zarządzaniu majątkiem klasztornym czy też naganny, nieprzystający dla osoby duchownej, styl życia ${ }^{33}$.

Wacław Kowiński urodził się w 1761 r. Do konwentu sieciechowskiego dołączył w 1781 r., a w 1788 r. ukończył nowicjat. W klasztorze pełnił urząd podprzeora. Po kasacie opactwa w maju 1820 r. został przeniesiony na czasowe zastępstwo do parafii Wolanów, z powodu choroby ks. Tomasza Bilskiego, miejscowego proboszcza $^{34}$. W $1821 \mathrm{r}$. został wikariuszem w parafii Sucha, gdzie zmarł 10 maja 1822 r. w wieku 61 lat $^{35}$.

Emilian Wąsicki był najstarszym mnichem sieciechowskim w czasie supresji opactwa. Urodził się w 1743 r. i pochodził z obszaru Śląska Pruskiego. Do klasztoru sieciechowskiego wstąpił w 1767 r., a trzy lata później ukończył tam nowicjat. Po kasacie opactwa pozostał w Sieciechowie mimo podanej w protokole ewakuacyjnym deklaracji powrotu do rodziny ${ }^{36}$. W styczniu $1821 \mathrm{r}$. Deputacja SZID, w piśmie do Komisji Województwa Sandomierskiego, skierowała prośbę do księżnej Teodory Jabłonowskiej, dzierżawczyni dóbr sieciechowskich, czy za stosownym wynagrodzeniem zechciałaby utrzymywać dwóch zakonników, E. Wąsickiego i E. Febeuriera, którzy nie mieli zapewnionych miejsc w innych wspólnotach klasztornych ani na placówkach parafialnych ${ }^{37}$. Księżna widocznie udzieliła odmownej odpowiedzi, skoro zakonnicy w tym i późniejszym czasie

${ }^{29}$ ADS, Akta benedyktyni Sieciechów 1804-1823, s. 479.

${ }^{30}$ ADS, Akta parafii Sieciechów (1797-1841), bez sygn.

${ }^{31}$ APR, Urząd Stanu Cywilnego Parafii Rzymskokatolickiej Sieciechów, sygn. 28, s. 95, nr 40. Por. Stownik biograficzny księży, t. 2, s. 179 (gdzie data śmierci 21 V 1838).

${ }^{32}$ Gacki, Benedyktyński klasztor w Sieciechowie, s. 167.

${ }^{33}$ ADS, Akta personalne ks. Hipolita Kurosza; ADS, Akta benedyktyni Sieciechów 1804-1823, s. $112-150,486-578$.

${ }^{34}$ ADS, Akta personalne ks. Wacława Kowińskiego, k. 2-5; J. Wiśniewski, Dekanat radomski, Radom 1911, s. 381.

${ }^{35}$ APR, Urząd Stanu Cywilnego Parafii Rzymskokatolickiej Sucha, sygn. 12, s. 53, nr 14.

${ }^{36}$ APR, ZDP, Sukcesje, sygn. 1226, k. 105r; Consignatio Dioecesis Sandomiriensis 1824, s. 113.

${ }^{37}$ Tamże, k. 88r-88v. 
wykazują inne niż klasztor miejsce pobytu. E. Wąsicki zmarł 26 listopada $1824 \mathrm{r}$. we wsi Podzator (dzisiejsze Opactwo) w pobliżu Sieciechowa w wieku 81 lat ${ }^{38}$.

Leander Herczewicz urodził się w 1761 r. Jako miejsce swojego pochodzenia wskazywał Galicję pod zaborem austriackim. Do klasztoru sieciechowskiego wstąpił w 1779 r., a w 1785 r. ukończył tam nowicjat. Przez pewien czas przebywał poza konwentem klasztornym, ponieważ władze wyznaniowe w $1817 \mathrm{r}$. wyraziły zgodę na jego ponowne włączenie do zgromadzenia sieciechowskiego ${ }^{39}$. W 1819 r. liczył 58 lat i miał problemy ze słuchem. Po kasacie opactwa został kapelanem w Sobolewie w diecezji podlaskiej w parafii Maciejowice, w kaplicy odbudowanej przez dziedziców Szczakowskich ${ }^{40}$. Zmarł w Sobolewie 25 marca 1822 r. w wieku 62 lat $^{41}$.

Paweł Maicki urodził się w 1776 r. w Pułtusku, gdzie pobierał nauki początkowe w szkole elementarnej. Następnie kształcił się w gimnazjum w Ciechanowie. W 1797 r. rozpoczął nowicjat w klasztorze sieciechowskim, gdzie studiował filozofię. W klasztorze na Świętym Krzyżu odbył studia w zakresie nauk teologicznych i prawa kanonicznego. W dniu 28 czerwca 1807 r. przyjął święcenia kapłańskie. W 1810 r. został wikariuszem w parafii Bobrowniki, gdzie spędził dwa i pół roku. Następnie powrócił do klasztoru sieciechowskiego ${ }^{42}$. W 1817 r. został administratorem kościoła w Brzeźnicy, będącego filią probostwa w Sieciechowie, gdzie pozostał po kasacie opactwa do dnia swojej śmierci 4 sierpnia $1837 \mathrm{r}^{43}$

Beda Lipowski urodził się w 1776 r. w miejscowości Niskie ${ }^{44}$. W 1799 r. wstąpił do klasztoru sieciechowskiego, gdzie cztery lata później ukończył nowicjat. Był profesorem i wicerektorem przyklasztornej szkoły podwydziałowej w Sieciechowie, w której nauczał arytmetyki, geometrii i fizyki ${ }^{45}$. Po kasacie opactwa przez dwa lata pełnił obowiązki kapelana u księstwa Jabłonowskich, właścicieli klucza dóbr pobliskiego Dęblina ${ }^{46}$. Następnie wrócił do Sieciechowa, gdzie $\mathrm{w}$ roli wikariusza pomagał $\mathrm{w}$ obowiązkach duszpasterskich proboszczowi H. Kuroszowi ${ }^{47}$. W styczniu 1828 r. według zarządzenia biskupa przy-

${ }^{38}$ APR, Urząd Stanu Cywilnego Parafii Rzymskokatolickiej Sieciechów, sygn. 14, s. 102, nr 54.

${ }^{39}$ ADS, Akta benedyktyni Sieciechów 1804-1823, s. 490-491.

${ }^{40}$ ADS, Akta zakonne różne (1820-1824), b.p., List przeora H. Kurosza do konsystorza generalnego diecezji sandomierskiej, Sieciechów 5 IX 1821.

${ }^{41}$ Parafia Maciejowice 1797-2016. Wyniki indeksacji ksiag metrykalnych wykonanej przez Garwolińską Grupę Indeksacyjna, 2017, s. 1924, http:/garwolin.org/maciejowice_indeksy (dostęp: 26.09.2018).

${ }^{42}$ ADS, Akta konduit. Stan służby kapłanów 1835, t. 1, nr 135.

${ }^{43}$ APR, Urząd Stanu Cywilnego Parafii Rzymskokatolickiej Brzeźnica, sygn. 26, s. 33, nr 48; ADS, Akta wizytacji dziekańskich (1827-1835), k. 2; Por. Słownik biograficzny księży, t. 3, s. 16 (gdzie inna data śmierci); J. Wiśniewski, Dekanat kozienicki, Radom 1913, s. 3.

${ }^{44}$ Obecnie miejscowość Niskie położona jest w powiecie przasnyskim w województwie mazowieckim.

${ }^{45}$ AGAD, CWWKP, sygn. 796, s. 528-529.

${ }^{46}$ G. Szczepańska, Kalendarium Dęblina, Dęblin 2014, s. 8-11.

${ }^{47}$ ADS, Akta personalne ks. Kazimierza Lipowskiego, b.p. Plik kilku dokumentów dotyczących Bedy Lipowskiego znajduje się w teczce personalnej innego zakonnika sieciechowskiego o tym samym nazwisku. 
był do Sandomierza, gdzie został umieszczony w domu ojców reformatów. Zmarł 19 stycznia $1828 \mathrm{r}$. w wieku 52 lat, po zaledwie jednym tygodniu pobytu w Sandomierzu ${ }^{48}$.

Bernard Dutkowski w 1806 r. ukończył nowicjat w klasztorze sieciechowskim $^{49}$. W latach 1813-1816 sprawował posługę komendarza kościoła filialnego w Brzeźnicy ${ }^{50}$. W 1816 r. wyraził zainteresowanie objęciem funkcji kapelana wojskowego w związku z apelem władz rządowych o potrzebie uzupełnienia braków kadrowych w nowo tworzonej armii ${ }^{51}$. Służba wojskowa stanowić miała formę wynagrodzenia straty po zmarłym bracie Piotrze Dutkowskim, który jako żołnierz w 1812 r. zginął w bitwie pod Możajskiem ${ }^{52}$. W październiku 1816 r. B. Dutkowski otrzymał oficjalną nominację na kapelana 3 Pułku Strzelców Konnych ${ }^{53}$. Kapelani w armii Królestwa Polskiego pełnili szereg obowiązków duszpasterskich, m.in. odprawiali msze św., udzielali sakramentów oraz byli urzędnikami stanu cywilnego dla osób wojskowych ${ }^{54}$. Po kasacie opactwa sieciechowskiego B. Dutkowski pozostał w wojsku jako kapelan do 1824 r., gdy na własne żądanie otrzymał dymisję ${ }^{55}$. Nie znamy jego dalszych losów.

Kolumban Jastrzębski urodził się 23 września 1782 r. w Kozienicach jako syn Wojciecha i Marianny ${ }^{56}$. Na chrzcie św. otrzymał imię Michał. W latach 17921795 kształcił się w szkole pijarów w Radomiu, a następnie do 1800 r. w szkole benedyktynów w Sieciechowie. Święcenia kapłańskie przyjął 17 grudnia 1808 r.

${ }^{48}$ Archiwum Państwowe w Kielcach Oddział w Sandomierzu, Akta stanu cywilnego Parafii Rzymskokatolickiej Katedralnej pw. Narodzenia Najświętszej Maryi Panny w Sandomierzu, sygn. 33 , s. 59 , nr 4.

${ }^{49} \mathrm{~W}$ materiale źródłowym pojawiają się różne daty urodzenia B. Dutkowskiego - $1780 \mathrm{r}$. oraz 1782 r. W piśmie do KRWRiOP z października 1816 r. B. Dutkowski informował, że ma 34 lata, 16 lat jest zakonnikiem i 4 lata zarządza kościołem brzeźnickim. Por. ADS, Akta kapelanów 18121838, k. 37r.

${ }^{50}$ ADS, Akta benedyktyni Sieciechów 1804-1823, s. 410; Wiśniewski, Dekanat kozienicki, s. 4.

${ }^{51}$ Książe Konstanty w listopadzie 1815 r. zwrócił się do administratora diecezji warszawskiej, ks. Ignacego Raczyńskiego, z prośbą o wyznaczenie kandydatów na wakujące stanowiska kapelanów wojskowych. Podobne pismo, z prośbą o przesłanie listy osób duchownych zainteresowanych pełnieniem obowiązków kapelana, w grudniu 1815 r. do biskupa kieleckiego Wojciecha Górskiego, skierował minister wojny Królestwa Polskiego Józef Wielhorski. Odezwa w tej sprawie została ponowiona jeszcze w marcu 1816 r. przez KRWRiOP. Zob. ADS, Akta kapelanów (1812-1838), k. 20r, 23r; D. Chodyniecki, Kapelani wojskowi w dziejach Polski do wybuchu II wojny światowej, „Saeculum Christianum”, 4 (1997) z. 2, s. 124-125; E.M. Ziółek, Duszpasterstwo w wojsku Księstwa Warszawskiego, Królestwa Polskiego i po powstaniu listopadowym, w: Historia duszpasterstwa wojskowego na ziemiach polskich, red. J. Ziółek i inni, Lublin 2004, s. 177-178.

${ }^{52}$ ADS, Akta kapelanów (1812-1838), k. 37r.

${ }^{53}$ Tamże, k. 35r-35v, 47r, 48r, 69r-69v, 70r.

${ }^{54}$ P.P. Gach, Zakonni kapelani wojskowi pod koniec XVIII $i$ w XIX stuleciu, w: Historia duszpasterstwa wojskowego na ziemiach polskich, s. 247.

${ }^{55}$ Rocznik Woyskowy Królestwa Polskiego na rok 1824, Warszawa 1824, s. 113, 201; Rocznik Woyskowy Królestwa Polskiego na rok 1825, Warszawa 1825, s. 116. Por. E. Nowak, Rys dziejów duszpasterstwa wojskowego w Polsce 968-1831, Warszawa 1932, s. 147.

${ }^{56}$ Archiwum Parafialne w Kozienicach, Księga urodzeń 1773-1783, s. 154, nr 1129. 
z rąk bpa ks. Franciszka Zambrzyckiego, sufragana kijowskiego. Był prefektem młodzieży zakonnej, nauczycielem w gimnazjum sieciechowskim, sekretarzem kapituly oraz prowizorem dóbr klasztornych. Po kasacie opactwa przez jedenaście miesięcy przebywał w Zbyczynie koło Sieciechowa, gdzie z polecenia starosty stężyckiego zajmował się wychowywaniem sierot. W grudniu 1821 r. został proboszczem parafii Ciepielów, w której z jego inicjatywy w późniejszym czasie powstała szkoła elementarna ${ }^{57}$. Zmarł w Ciepielowie 15 sierpnia 1842 r. w wieku 61 lat, po ponad dwudziestu latach posługi duszpasterskiej w parafii ${ }^{58}$.

Augustyn Kędzierski urodził się 11 listopada 1785 r. w Koprzywnicy ${ }^{59}$. Po ukończeniu gimnazjum w Wąchocku rozpoczął nowicjat w klasztorze sieciechowskim, gdzie studiował filozofię i teologię. W 1813 r. przyjął święcenia kapłańskie. Był profesorem i nauczycielem w szkole przyklasztornej, a następnie mistrzem nowicjatu. W listopadzie 1817 r. razem z H. Kasperowiczem złożył do biskupa skargę na przeora H. Kurosza o doznane z jego strony krzywdy oraz o trwonienie majątku opactwa. Zapewne w związku z tą sprawą w $1818 \mathrm{r}$. został przeniesiony jako wikariusz do parafii w Rakowie. W maju 1821 r. został administratorem parafii Szumsko w zastępstwie chorego księdza proboszcza ${ }^{60}$. W listopadzie $1825 \mathrm{r}$. otrzymał probostwo w Waśniowie, które sprawował do śmierci w dniu 17 stycznia $1836 \mathrm{r}^{61}$

Antoni Kowalski urodził się 21 września 1788 r. w Rzeczkowie jako syn Błażeja i Marianny z domu Czarnecka ${ }^{62}$. Na chrzcie św. w kościele parafialnym w Wierzbicy otrzymał imię Mateusz. Po ukończeniu gimnazjum w Wąchocku w 1807 r. wstąpił do klasztoru benedyktynów w Sieciechowie, gdzie studiował filozofię i teologię. W dniu 21 grudnia 1813 r. otrzymał święcenia kapłańskie. Był profesorem i wicerektorem szkoły podwydziałowej w Sieciechowie, gdzie nauczał religii, obyczajów i konstytucji krajowej ${ }^{63}$. Po kasacie opactwa został wikariuszem parafii w Jeżowie w archidiecezji warszawskiej (1819-1820) oraz wikariuszem i nauczycielem szkoły elementarnej w Zwoleniu (1820-1824) ${ }^{64}$. W dniu

${ }^{57}$ H. Kowalska-Kutera, A. Jaskulska, H. Nowakowska, Parafia Podwyższenia Krzyża Świętego, w: Ciepielów dawniej i dziś, red. H. Bednarczyk, H. Kowalska-Kutera, Sycyna 2001, s. 161.

58 Archiwum Państwowe w Kielcach, Akta stanu cywilnego Parafii Rzymskokatolickiej w Ciepielowie, sygn. 80, s. 99, nr 83; ADS, Akta personalne ks. Michała Kolumbana Jastrzębskiego; J. Wiśniewski, Dekanat ilżecki, Radom 1912, s. 43; Stownik biograficzny księży, t. 2 , s. 42.

${ }^{59}$ Por. Stownik biograficzny księży, t. 2, s. 80 (gdzie inny data urodzenia).

${ }^{60}$ ADS, Akta personalne ks. Augustyna Kędzierskiego; ADS, Akta benedyktyni Sieciechów 1804-1823, s. 486-488; ADS, Akta konduit. Stan służby kapłanów 1835, t. 1, nr 106; J. Wiśniewski, Dekanat opatowski, Radom 1907, s. 501, 511.

${ }^{61}$ ADS, Akta parafii Waśniów (1797-1829), k. 190; ADS, Akta parafii Waśniów (1836-1844), k. 2.

${ }^{62}$ Data urodzenia A. Kowalskiego jest różnie podawana w materiale źródłowym. Por. ADS, Akta personalne ks. Antoniego Kowalskiego; ADS, Akta konduit. Stan służby kapłanów 1835, t. 1, nr 115; APR, ZDP, Sukcesje, sygn. 1225, k. 39r-40r; Stownik biograficzny księży, t. 2, s. 136.

${ }^{63}$ AGAD, CWWKP, sygn. 796, s. 528-529.

${ }^{64}$ ADS, Akta konduit. Stan służby kapłanów 1835, t. 1, nr 115; A. Skała, Kościół Podwyższenia Krzyża Świętego w Zwoleniu, Lublin 1998, s. 97-99; S. Piątkowski, A. Szymanek, Parafia 
18 lipca 1824 r. objął parafię w Kowali Stępocińskiej, gdzie pozostał do 1856 r. ${ }^{65}$ Wtedy został mianowany administratorem kościoła na Łysej Górze, gdzie zmarł 4 marca $1864 \mathrm{w}$ wieku 76 lat $^{66}$.

Hilary Kasperowicz urodził się w 1790 r. Do zgromadzenia sieciechowskiego dołączył w 1811 r., a trzy lata później ukończył tam nowicjat. Był wykładowcą studium zakonnego na Świętym Krzyżu w roku akademickim 1819/1820 ${ }^{67}$. W 1818 r. razem z Augustynem Kędzierskim został mianowany wikariuszem parafii w Rakowie. W 1821 r. objął probostwo daniszewskie w diecezji płockiej ${ }^{68}$. W sierpniu 1826 r. został przeniesiony do parafii Ceranów w diecezji podlaskiej, gdzie pozostał do dnia swojej śmierci 29 stycznia 1838 r. Piastował godność kanonika Kapituły Kolegiaty Pułtuskiej oraz kanonika Katedry Lubelskiej ${ }^{69}$.

Izydor Makowiecki urodził się w 1792 r. w Zwoleniu. Po ukończeniu szkoły powiatowej w Sieciechowie wstąpił do nowicjatu w miejscowym klasztorze benedyktynów. Studia odbył w Seminarium Duchownym w Lublinie. Święcenia kapłańskie przyjął 8 grudnia 1817 r. z rąk bpa Tomasza Nowińskiego. Po kasacie opactwa do 1824 r. był wikariuszem w parafii Zwoleń. Następnie otrzymał nominację na probostwo w Górze Jaroszyńskiej (obecnie Góra Puławska), gdzie pozostał do śmierci 15 lutego $1831 \mathrm{r}^{70}$ Nie znamy dokładnych okoliczności śmierci kapłana, ale mogły być one związane z trwającymi w tamtym czasie walkami powstania listopadowego na terenie powiśla puławskiego ${ }^{71}$.

Kajetan Strasz urodził się 4 lutego 1791 r. we wsi Belsk w ziemi czerskiej ${ }^{72}$. $\mathrm{Na}$ chrzcie św. otrzymał imię Bazyli. W 1809 r. podjął służbę wojskową w armii Księstwa Warszawskiego. Brał udział w wojnach napoleońskich, w tym wojnie polsko-austriackiej w 1809 r., kampanii rosyjskiej w 1812 r., następnie w bitwach pod Lipskiem i Lützen w 1813 r. oraz kampanii francuskiej w 1814 r. $^{73} \mathrm{~W}$ roku 1815 na własne żądanie otrzymał zwolnienie ze służby wojskowej, wtedy też do-

Podwyższenia Krzyża Świętego w Zwoleniu 1425-2002. Monografia historyczna, Zwoleń 2002 (nie został wymieniony w wykazie wikariuszy).

${ }^{65}$ Por. Stownik biograficzny księży, t. 2, s. 136; Wiśniewski, Dekanat radomski, s. 146.

${ }^{66}$ Archiwum Państwowe w Kielcach, Akta stanu cywilnego Parafii Rzymskokatolickiej w Słupi Nowej, sygn. 109, nr 29.

${ }^{67}$ Kanior, Końcowe dzieje, s. 594; tenże, Polska Kongregacja Benedyktyńska, s. 261.

${ }^{68}$ ADS, Akta personalne ks. Hilarego Kasperowicza, k. 3-5; ADS, Akta parafii Raków (18011844), k. 50-51, 132-133; Wiśniewski, Dekanat opatowski, s. 387.

${ }^{69}$ AGAD, CKKWP, sygn. 669, k. 87, 97, 103-105, 109; Rocznik Instytutów Religiynych i Edukacyinych w Królestwie Polskiem 1826, wyd. J.A. Radomiński, Warszawa 1826-1827, s. 158.

${ }^{70}$ Archiwum Państwowe w Lublinie, Akta stanu cywilnego Parafii Rzymskokatolickiej w Górze Jaroszyn, sygn. 21, s. 18, nr 11 (akt zgonu podaje, że zmarł w wieku 47 lat); Por. Słownik biograficzny księży, t. 3, s. 22; Wiśniewski, Dekanat kozienicki, s. 33 (gdzie data śmierci 1829 r.); ADS, Akta sekularyzacji zakonników (1812-1844), b.p., Pisma związane z sekularyzacją zakonnika z 1 i 4 IX 1824.

71 W.W. Bednarski, Pulawskie w okresie powstania listopadowego 1830/31r., w: Studia Pulawskie, red. W.W. Bednarski, Puławy 1974, s. 158-163.

${ }^{72}$ Obecnie miejscowość Belsk położona jest w powiecie grójeckim w województwie mazowieckim.

${ }^{73}$ AGAD, Komisja Rządowa Wojny, sygn. 354, k. 135-136. 
łączył do zgromadzenia benedyktynów w Sieciechowie. Studia w zakresie nauk teologicznych odbył w Seminarium Duchownym w Warszawie. Święcenia kapłańskie przyjął 8 grudnia 1818 r. $^{74}$ Po kasacie opactwa 1 lutego 1820 r. został kapelanem wojskowym w 4. Pułku Strzelców Pieszych, wchodzącym w skład 3. Brygady 2. Dywizji Piechoty ${ }^{75}$. Funkcję kapelana pełnił w Twierdzy Zamość, gdzie stacjonował sztab 4. Pułku, do czasu likwidacji Wojska Polskiego po powstaniu listopadowym ${ }^{76}$. W 1832 r. został administratorem parafii Żółkiewka, a następnie proboszczem parafii w Wąwolnicy (1834-1837) i Tarnogrodzie (1837-1847). Jako proboszcz Tarnogrodu skierowal raport do gubernatora lubelskiego w sprawie niebezpieczeństwa ekspansji prawosławia na terenie parafii ${ }^{77}$. Po serii konfliktów na tym tle, zmuszony był przenieść się w 1847 r. do parafii w Wilkołazie, gdzie pozostał jako proboszcz do dnia swojej śmieci 8 maja $1856 \mathrm{r}^{78} \mathrm{~W} 1838 \mathrm{r}$. otrzymał godność kanonika honorowego Kapituły Kolegiaty Zamojskiej ${ }^{79}$.

Emilian Febuerier, francuski emigrant z Niderlandów, w czasie kasaty opactwa od 15 lat przebywający już na ziemiach polskich, do konwentu sieciechowskiego dołączył $\mathrm{w} 1817 \mathrm{r}^{80}$ Po supresji opactwa mieszkał w prywatnym domu przyjaciela Remigiana Kurdwanowskiego w Klwatce Szlacheckiej pod Radomiem. W 1821 r. poprosił o umieszczenia w klasztorze bernardynów w Radomiu, na co zgodę wyraziła KRWRiOP przyznając mu 600 złp pensji ${ }^{81}$. Zmarł 4 marca 1826 r. jako kapelan w Klwatce Szlacheckiej w wieku 60 lat ${ }^{82}$.

${ }^{74}$ Archiwum Archidiecezjalne Lubelskie (dalej: AAL), Konsystorz Generalny Lubelski (KGL), sygn. Rep. 60 A 252, k. 85-86, nr 145.

${ }^{75}$ Rocznik Woyskowy Królestwa Polskiego na rok 1830, Warszawa 1830, s. 103, 205; B. Gembarzewski, Wojsko Polskie 1815-1830, Warszawa 1903, s. 185-186; Nowak, Rys dziejów duszpasterstwa, s. 146, 154, 166.

${ }^{76}$ W. Śladkowski, Ostatni bastion powstania listopadowego, w: Zamość: z przeszłości twierdzy i miasta, red. A. Koprukowniak, A.A. Witusik, W. Ćwik, Lublin 1980, s. 164-181; B. Gembarzewski, Rodowody pułków polskich i oddziatów równorzędnych od r. 1717 do 1831, Warszawa 1925, s. 76; J. Wimmer, Historia piechoty polskiej do roku 1864, Warszawa 1978, s. 461.

${ }^{77}$ W. Depczyński, Parafia Tarnogród, „Nasza Przeszłość”, 37 (1972) s. 195; M. Mądzik, Z zagadnień polityki wyznaniowej na pograniczu Królestwa Polskiego w okresie międzypowstaniowym (na przyktadzie Tarnogrodu), w: Na pograniczu kultur, języków i tradycji. Prace ofiarowane profesorowi doktorowi Ryszardowi Szczygłowi w sześćdziesiąta rocznicę urodzin, red. M. Mądzik, A.A. Witusik, Lublin 2004, s. 230, 233-239; T. Osiński, „Propaganda luchowska”. Kulisy konwersji na prawosławie unitów wsi Luchów, Babice, Potok Górny w latach czterdziestych XIX wieku, „Res Historica", 26 (2008) s. 72, 88.

${ }^{78}$ Archiwum Parafialne w Wilkołazie, Akta zmarłych 1851-1863, s. 133, nr 62, https://www. familysearch.org/ (dostęp: 26.09.2018); Wykaz duchownych świeckich zmartych w ciagu roku 1856 w Królestwie Polskim, „Pamiętnik Religijno-Moralny”, 33 (1857) z. 7, s. 81.

${ }^{79}$ F. Stopniak, Dzieje Kapituly Zamojskiej, Lublin 1962, s. 195. Dziękuję Pani Bożennie Dereckiej-Dupuis oraz Panu Markowi Straszowi za okazaną pomoc przy ustalaniu biogramu ks. K. Strasza.

${ }^{80}$ ADS, Akta benedyktyni Sieciechów 1804-1823, s. 490-491; APR, ZDP, Sukcesje, sygn. 1226, k. 105v; Gacki, Benedyktyński klasztor w Sieciechowie, s. 159.

${ }^{81}$ ADS, Akta benedyktyni Sieciechów 1804-1823, s. 635-636.

${ }^{82}$ APR, Urząd Stanu Cywilnego Parafii Rzymskokatolickiej Radom, sygn. 7, s. 405, nr 57; Consignatio Dioecesis Sandomiriensis 1826, s. 116. 
Kazimierz Lipowski urodził się 30 września 1797 r. w miejscowości Niskie jako syn Kazimierza i Rozalii ${ }^{83}$. Wraz z ukończeniem szkoły powiatowej w Sieciechowie rozpoczął nowicjat w miejscowym klasztorze benedyktynów. Po kasacie opactwa kontynuował studia teologiczne w Seminarium Duchownym Księży Misjonarzy w Lublinie. 20 września 1820 r. przyjął święcenia kapłańskie. W latach 1820-1825 pracował jako wikariusz w parafiach Trójca i Tarłów, a następnie był administratorem w parafii Grzegorzewice. W latach 1825-1853 pełnił funkcję proboszcza parafii Smogorzów ${ }^{84}$. W dniu 1 lutego 1854 r. postanowieniem Rady Administracyjnej Królestwa Polskiego objął obowiązki proboszcza parafii Nowa Słupia i regensa Instytutu Księży Demerytów na Łysej Górze. W 1854 r. otrzymał godność kanonika honorowego Kapituły Katedralnej w Lublinie ${ }^{85}$. Zmarł w Nowej Słupi 30 listopada 1855 r. w wieku 58 lat $^{86}$.

Adam Staszewski urodził się 15 czerwca 1798 r. w Podzatorze nieopodal Sieciechowa jako syn Michała i Heleny z domu Majorowicz. Na chrzcie św. otrzymał imię Antoni. Po ukończeniu nauk podstawowych w szkole sieciechowskiej, wstąpił do klasztoru benedyktynów, gdzie złożył profesję zakonną. Po supresji opactwa przez rok pobierał nauki filozoficzne i teologiczne w Seminarium Duchownym Księży Misjonarzy w Lublinie. Później przeniósł się do Seminarium Duchownego w Sandomierzu, gdzie 26 czerwca 1825 r. przyjął święcenia ka-

${ }^{83}$ Obecnie miejscowość Niskie położona jest w powiecie przasnyskim w województwie mazowieckim.

${ }^{84}$ Według akt stanu służby kapłanów K. Lipowski w 1831 r. miał pełnić obowiązki kapelana w szeregach powstańców listopadowych, a po upadku powstania powrócić na plebanię do Smogorzowa. W listopadzie 1853 r. Komisja Rządowa Spraw Wewnętrznych i Duchownych zwróciła się do administratora diecezji sandomierskiej, ks. Klemensa Bąkiewicza, z prośbą o zasięgnięcie informacji w tej sprawie. Komisja zabiegała o uzyskanie informacji potwierdzających i wyjaśniających decyzję kapłana o udziale w powstaniu, ponieważ od tego uzależniała akceptację nominacji K. Lipowskiego na beneficjum w Nowej Słupi. Władze diecezji udzieliły odpowiedzi, że nie znajdują w swoich dokumentach żadnych informacji związanych z nominacją czy wezwaniem do pełnienia przez K. Lipowskiego funkcji kapelana w czasie powstania. Sam zainteresowany udzielił wyjaśnień, że nie opuszczał parafii w Smogorzowie w tym czasie. Sprawa nominacji na parafię w Nowej Słupi rozstrzygnęła się korzystnie dla kapłana. Udział K. Lipowskiego w powstaniu potwierdzają inne dokumenty, które dowodzą, że w maju $1831 \mathrm{r}$. został on mianowany kapelanem wojskowym 2. Pułku Jazdy Sandomierskiej, a w końcu października powrócił na parafię w Smogorzowie po załatwieniu pewnych spraw wojskowych i cywilnych. Zapisy aktów stanu cywilnego również wskazują, że proboszcz opuścił parafię na okres kilku miesięcy w $1831 \mathrm{r}$. Zob. ADS, Akta konduit. Stan służby kapłanów 1835, t. 1, nr 127; ADS, Akta kapelanów (1812-1838), k. 174r-174v, 175r, 304r, 313r; Archiwum Państwowe w Kielcach, Akta stanu cywilnego Parafii Rzymskokatolickiej w Smogorzowie, sygn. 22.

${ }^{85}$ ADS, Akta personalne ks. Kazimierza Lipowskiego, b.p.; ADS, Akta konduit. Stan służby kapłanów 1835, t. 1, nr 127; Gacki, Benedyktyński klasztor Świętego Krzyża, s. 341; Por. Stownik biograficzny księży, t. 2, s. 208-209.

${ }^{86}$ Archiwum Państwowe w Kielcach, Akta stanu cywilnego Parafii Rzymskokatolickiej w Słupi Nowej, sygn. 91, nr 177; AGAD, CWWKP, sygn. 723, s. 47-50, 154, 158; A. Massalski, Miejsce pokuty i poniżenia. Instytut Księży Zdrożnych (1853-1863) $i$ więzienie rosyjskie (1886-1914) na Świętym Krzyżu, w: Klasztor na Świętym Krzyżu, s. 186. 
płańskie z rąk bpa Adama Prospera Burzyńskiego ${ }^{87}$. Następnie do 1828 r. był wikariuszem parafii Trójca oraz przez 15 tygodni pełnił obowiązki wikariusza i mansjonarza w parafii Bodzentyn. W latach 1828-1834 był wikariuszem parafii Wojciechowice, skąd wyznaczony został na administratora wakującej parafii w Kleczanowie. W 1837 r. został wikariuszem parafii Raków, gdzie w szkole parafialnej nauczał katechezy i nauk obyczajowo-moralnych. W 1845 r. przez krótki czas był administratorem parafii Zagnańsk, skąd przeszedł na wikariat do Nowej Słupi. W latach 1849-1864 był proboszczem w parafii Świerże, gdzie wybudował plebanię. W latach 1855-1857 sprawował też posługę w sąsiedniej parafii w Ryczywole. W lipcu 1864 r. został mianowany administratorem kościoła na Łysej Górze, gdzie z powodów zdrowotnych przybył dopiero na przełomie października i listopada 1865 r. Zmarł 3 maja 1871 r. w wieku 73 lat. Podczas ogrzewania się ciepłem kominka, zapalił się na nim habit, porwany silnym prądem powietrza ${ }^{88}$.

Laurenty Brekowski urodził się w 1797 r. w miejscowości Świniary w dawnym województwie podlaskim ${ }^{89}$. Na chrzcie św. otrzymał imię Dominik. Do klasztoru sieciechowskiego wstąpił w $1816 \mathrm{r}$. W szkole sieciechowskiej nauczał geografii, historii Polski i powszechnej. Po kasacie opactwa zrezygnował z życia osoby duchownej, dlatego też złożył suknię zakonną i jako osoba świecka opuścił klasztor $^{90}$. Nie znamy jego dalszych losów.

Szymon Orłowski urodził się 6 października 1799 r. w Koprzywnicy jako syn Benedykta i Reginy z domu Hamerska. Po ukończeniu szkoły wydziałowej w Koprzywnicy rozpoczął nowicjat w klasztorze benedyktynów na Łysej Górze. W zgromadzeniu sieciechowskim, do którego dołączył w 1815 r., przybrał imię zakonne Placyd. W miejscowej szkole klasztornej był nauczycielem historii naturalnej, techniki i języka polskiego ${ }^{91}$. Po kasacie opactwa został umieszczony w Seminarium Duchownym w Lublinie, gdzie 9 czerwca 1822 r. otrzymał święcenia kapłańskie ${ }^{92}$. W latach 1822-1827 pełnił posługę wikariusza w parafii Kurów, następnie do 1834 r. był komendarzem kościoła w Piotrawinie ${ }^{93}$. W latach 18351853 był proboszczem parafii w Rybitwach, gdzie zmarł 13 marca 1853 r. w wieku 54 lat $^{94}$.

${ }^{87}$ S. Kotkowski, Seminarium Duchowne w Sandomierzu w latach 1820-1926, Sandomierz 2010, s. 147; Consignatio Dioecesis Sandomiriensis 1824, s. 102.

${ }^{88}$ ADS, Akta personalne ks. Adama Staszewskiego; ADS, Akta konduit. Stan służby kapłanów 1835, t. 1, nr 215; J. Wiśniewski, Dekanat sandomierski, Radom 1915, s. 47; tenże, Dekanat kozienicki, s. 145, 168, 173; Gacki, Benedyktyński klasztor Świętego Krzyża, s. 167-168, 341; Kanior, Końcowe dzieje, s. 598.

${ }^{89}$ Obecne położenie miejscowości jest trudne do ustalenia.

${ }^{90}$ ADS, Akta benedyktyni Sieciechów 1804-1823, s. 610; AGAD, CWWWKP, sygn. 796, s. 528-529.

${ }^{91}$ AGAD, CWWWKP, sygn. 796, s. 528-529.

${ }^{92}$ AAL, KGL, sygn. Rep. 60 VIII 36, vol. 2, k. 148, 151; vol. 3, k. 4.

${ }^{93}$ AAL, KGL, sygn. Rep. 60 A 252, k. 64, nr 109.

${ }^{94}$ APL, Akta stanu cywilnego Parafii Rzymskokatolickiej w Rybitwach, sygn. 56, s. 38, nr 14; Consignatio Cleri Saecularis ac Regularis Dioecesis Lublinensis pro Anno Domini 1840 Confecta, s. 76; Tamże 1841, s. 66; Tamże 1846, s. 9. 
Bonifacy Trylinger urodził się w 1745 r. jako syn Ambrożego i Anny ${ }^{95}$. Jako miejsce swojego pochodzenia wskazywał miasto Wiedeń w Austrii. Do klasztoru sieciechowskiego wstąpił w $1814 \mathrm{r}$. W czasie spisywania protokołu okupacyjnego był mocno schorowany, doskwierała mu starcza ślepota i niedołężność ${ }^{96}$. Po kasacie opactwa na własne życzenie został umieszczony w klasztorze bonifratrów w Lublinie. W styczniu $1821 \mathrm{r}$. z przyczyn zdrowotnych został oddany na mieszkanie i kurację do Szpitala Braci Miłosierdzia, gdzie, po kilku miesiącach pobytu, zmarł w dniu 15 maja w wieku 76 lat $^{97}$.

Tomasz Orzechowski urodził się w 1761 r. Do konwentu sieciechowskiego dołączył w 1817 r. Po kasacie opactwa został umieszczony w klasztorze benedyktynów pułtuskich. W grudniu 1823 r. opuścił Pułtusk i według raportu dziekana kozienickiego widziany był w tamtejszym dekanacie ${ }^{98}$. Nie znamy jego dalszych losów.

Idzi Siennicki urodził się w 1796 r. w Nowej Wsi ${ }^{99}$. Do zgromadzenia sieciechowskiego dołączył w $1816 \mathrm{r}$. W szkole sieciechowskiej był nauczycielem literatury polskiej i łacińskiej ${ }^{100}$. Po kasacie opactwa, zgodnie z wolą pozostania w zakonie i dalszego kształcenia się w naukach teologicznych, został przeniesiony do klasztoru benedyktynów w Pułtusku. W późniejszym czasie został profesorem teologii i przez okres 30 lat nauczał w szkołach pułtuskich ${ }^{101}$. Z powodu patriotycznego zaangażowania zakonników w powstanie styczniowe w 1864 r. nastąpiła kasata miejscowego klasztoru. Benedyktynów przewieziono do Warszawy i umieszczono w klasztorze kamedułów na Bielanach ${ }^{102}$. Ten sam los podzielił I. Siennicki, który zmarł w klasztorze bielańskim kilka lat później, w dniu 5 czerwca 1870 r. w wieku 74 lat ${ }^{103}$.

${ }^{95}$ Ojciec zakonnika na jednym z dokumentów nosi imię Antoni. Por. AAL, KGL, sygn. Rep. 60 IX 41, b.p.

${ }^{96}$ APR, ZDP, Sukcesje, sygn. 1226, k. 106r.

${ }^{97}$ AAL, KGL, sygn. Rep. 60 IX 41, b.p.

${ }^{98}$ ADS, Akta zakonne różne (1820-1824), b.p.

${ }^{99}$ Obecnie miejscowość Nowa Wieś położona jest w powiecie wysokomazowieckim w województwie podlaskim.

${ }^{100}$ AGAD, CWWWKP, sygn. 796, s. 528-529.

${ }_{101}$ K. Wiśniewski, Szkolnictwo benedyktyńskie w Pultusku w latach 1781-1833, „Nasza Przeszłość”, 117 (2012) s. 205-214; tenże, Kościót św. Piotra i Pawła Apostołów oraz inne zabudowania jezuickie i benedyktyńskie w Pultusku (inwentarze z lat 1781-1882 oraz dokumentacja fotograficzna), „Hereditas Monasteriorum”, 5 (2014) s. 109-110, 113.

${ }^{102}$ Kanior, Końcowe dzieje, s. 606-607; K. Wiśniewski, Z dziejów konwentu benedyktynów w Pultusku w latach 1781-1864, w: Pultusk. Studia i materiaty z dziejów miasta i regionu, t. 6, red. J. Szczepański, Pułtusk 2005, s. 139-154.

103 J.I. Kraszewski, Nekrologi, „Tydzień Polityczny, Naukowy, Literacki i Artystyczny”, 19 czerwca 1870, nr 25, s. 246; Gacki, Benedyktyński klasztor w Sieciechowie, s. 168. 
$* * *$

Opracowane biogramy ostatnich zakonników zgromadzenia sieciechowskiego dowodzą, że po supresji opactwa w większości podjęli oni pracę duszpasterską w parafiach położonych na terenie kilku ówcześnie istniejących diecezji. Zakonnicy rezydujący już w ośrodkach parafialnych pozostali tam po kasacie opactwa. Dalsze losy kilku z nich związały się z beneficjami dawniej należącymi do klasztoru sieciechowskiego. Młodsi wiekiem w pierwszych latach posługi kapłańskiej sprawowali obowiązki wikariuszy, by następnie otrzymać nominację na proboszcza innej wspólnoty parafialnej. Niektórzy z nich zapisali się trwale na kartach historii swoich parafii jako sumienni kapłani oraz sprawni gospodarze dbający o zaplecze materialne kościoła. Trzech byłych zakonników sieciechowskich, dzięki przykładnie realizowanemu powołaniu kapłańskiemu, otrzymało godność kanonika kapituły kolegiackiej i katedralnej.

Początkowe losy członków konwentu sieciechowskiego przebiegały zgodnie z deklaracją złożoną w protokole ewakuacyjnym klasztoru. Część zakonników w starszym wieku, ze względu na zły stan zdrowia, wróciła do swoich krewnych bądź do śmierci pozostała w wyznaczonym im miejscu. Ta grupa benedyktynów zrezygnowała z pracy parafialnej, której podjęcie oznaczałoby utratę przyznanej im renty państwowej. Nowicjusze sieciechowscy zostali umieszczeni w seminariach duchownych, a po ukończeniu studiów i przyjęciu święceń kapłańskich, wstąpili w szeregi duchowieństwa diecezjalnego. Tylko jeden nowicjusz zdecydował się ostatecznie porzucić życie duchowne, co potwierdza, że ogólny odsetek zakonników, którzy po kasacie z 1819 r. rezygnowali z posługi duchownej, był stosunkowo nieduży ${ }^{104}$.

Zaledwie dwóch mnichów sieciechowskich zdecydowało się na przeniesienie do klasztoru w Pułtusku. Pozostali członkowie zgromadzenia, zwłaszcza młodsi wiekiem, woleli oczekiwać na ewentualną propozycję objęcia placówki parafialnej ${ }^{105}$. Dwóch benedyktynów po kasacie opactwa kontynuowało służbę w duszpasterstwie armii Królestwa Polskiego, a niektórzy zakonnicy w późniejszym czasie sprawowali obowiązki kapelanów w wojsku polskim w czasie powstania listopadowego. Działalność na tym polu potwierdza patriotyczne zaangażowania części duchowieństwa zakonnego w powstanie narodowe z lat 1830-1831 ${ }^{106}$.

W okresie kilku lat od supresji opactwa zmarło co najmniej sześciu najstarszych zakonników sieciechowskich. Najmłodsi bracia zakonni dożyli natomiast drugiej połowy XIX w. Trzech byłych zakonników sprawowało kolejno po sobie obowiązki administratora kościoła na Łysej Górze, skąd możliwe, że kilka wieków wcześniej przybyli pierwsi benedyktyni do nowo założonego klasztoru $\mathrm{w}$ Sieciechowie ${ }^{107}$. Po śmierci ostatniego z nich tradycja benedyktyńska w sank-

${ }^{104}$ Gach, Zakony w diecezji, s. 182-183; tenże, Kasaty zakonów, s. 110-115.

${ }^{105}$ Borowski, Dekret kasacyjny, s. 107.

${ }^{106}$ W. Saletra, Duchowieństwo obszaru między Wista a Pilica wobec powstania listopadowego 1830-1831, „Teka Komisji Historycznej”, 8 (2011) s. 159.

${ }^{107}$ Derwich, Monastycyzm benedyktyński, s. 194-195. 
tuarium Św. Krzyża, datująca się od czasów średniowiecza, została przerwana, a funkcje kapłańskie przejęli księża diecezjalni.

Zamieszczone biogramy nie oddają kontekstu psychologicznego towarzyszącego kasatom. Benedyktynom sieciechowskim zabrano nie tylko uposażenie materialne, przyznając w zamian niewielkie pensje na utrzymanie. Odebrano im coś cenniejszego, czyli poczucie ludzkiej godności i sprawiedliwości. Kasata przyniosła mnichom upokorzenie i rozgoryczenie, wprawiła w stan osamotnienia i niepewność tego co przyniesie przyszłośćc ${ }^{108}$. Odczucia te $\mathrm{z}$ pewnością towarzyszyły zakonnikom w kolejnych latach ich posługi duszpasterskiej, mimo że, pokasacyjne losy części z nich okazały się być dość pomyślne.

\section{BIBLIOGRAFIA}

\section{Źródla archiwalne}

Archiwum Archidiecezjalne Lubelskie

Konsystorz Generalny Lubelski

sygn. Rep. 60 IX 41; Rep. 60 VIII 36, vol. 2, 3; Rep. 60 A 252.

Archiwum Diecezjalne w Sandomierzu

Akta benedyktyni Sieciechów 1804-1823.

Akta konduit. Stan służby kapłanów 1835, t. 1.

Akta zakonne różne (1820-1824).

Akta wizytacji dziekańskich (1827-1835).

Akta sekularyzacji zakonników (1812-1844).

Akta kapelanów (1812-1838).

Akta parafii Sieciechów (1797-1841).

Akta parafii Waśniów (1797-1829).

Akta parafii Waśniów (1836-1844).

Akta parafii Raków (1801-1844).

Akta personalne ks. Hipolita Kurosza

Akta personalne ks. Wacława Kowińskiego

Akta personalne ks. Kazimierza Lipowskiego

Akta personalne ks. Michała Kolumbana Jastrzębskiego

Akta personalne ks. Augustyna Kędzierskiego

Akta personalne ks. Adama Staszewskiego

Akta personalne ks. Antoniego Kowalskiego

Akta personalne ks. Hilarego Kasperowicza

Archiwum Główne Akt Dawnych

Centralne Władze Wyznaniowe Królestwa Polskiego, sygn. 177, 178, 669, 723, 796, 797.

Komisja Rządowa Wojny, sygn. 354.

Archiwum Państwowe w Kielcach

Akta stanu cywilnego Parafii Rzymskokatolickiej w Ciepielowie, sygn. 80.

Akta stanu cywilnego Parafii Rzymskokatolickiej w Słupi Nowej, sygn. 91, 109.

Akta stanu cywilnego Parafii Rzymskokatolickiej w Smogorzowie, sygn. 22.

${ }^{108}$ Zawadzki, Losy franciszkanów, s. 95. 
Archiwum Państwowe w Kielcach, Oddział w Sandomierzu

Akta stanu cywilnego Parafii Rzymskokatolickiej Katedralnej pw. Narodzenia Najświętszej

Maryi Panny w Sandomierzu, sygn. 33.

Archiwum Państwowe w Lublinie

Akta stanu cywilnego Parafii Rzymskokatolickiej w Górze Jaroszyn, sygn. 21.

Akta stanu cywilnego Parafii Rzymskokatolickiej w Rybitwach, sygn. 56.

Archiwum Państwowe w Radomiu

Zarząd Rolnictwa i Dóbr Państwowych Guberni Radomskiej, Kieleckiej, Lubelskiej i Siedleckiej, Sukcesje, sygn. 1225, 1226, 1253, 1456.

Urząd Stanu Cywilnego Parafii Rzymskokatolickiej Brzeźnica, sygn. 13, 26.

Urząd Stanu Cywilnego Parafii Rzymskokatolickiej Sieciechów, sygn. 14, 28.

Urząd Stanu Cywilnego Parafii Rzymskokatolickiej Sucha, sygn. 12.

Urząd Stanu Cywilnego Parafii Rzymskokatolickiej Radom, sygn. 7.

Archiwum parafialne w Kozienicach

Księga urodzeń 1773-1783.

Archiwum parafialne w Wilkołazie

Akta zmarłych 1851-1863.

\section{Źródła drukowane}

Consignatio Cleri Saecularis ac Regularis Dioecesis Sandomiriensis pro Anno [1820$1841]$ Confecta.

Consignatio Cleri Saecularis ac Regularis Dioecesis Lublinensis pro Anno Domini [1840$1856]$ Confecta.

Rocznik Instytutów Religiynych i Edukacyinych w Królestwie Polskiem 1826, wyd. J.A. Radomiński, Warszawa 1826-1827.

Rocznik Woyskowy Królestwa Polskiego na rok 1824, Warszawa 1824.

Rocznik Woyskowy Królestwa Polskiego na rok 1825, Warszawa 1825.

Rocznik Woyskowy Królestwa Polskiego na rok 1830, Warszawa 1830.

\section{Opracowania}

Bednarski Waldemar Wojciech, Puławskie w okresie powstania listopadowego 1830/31r., w: Studia Puławskie, red. W.W. Bednarski, Puławy 1974, s. 147-171.

Borowski Franciszek Tadeusz, Dekret kasacyjny z roku 1819 i jego wykonanie w stosunku do zakonów diecezji sandomierskiej, „Studia Sandomierskie”, 18 (2011) z. 1, s. 7-162.

Brykowska Maria, W sprawie architektury zespołu pobenedyktyńskiego w OpactwieSieciechowie, „Kwartalnik Architektury i Urbanistyki”, 15 (1970) z. 2, s. 203-211.

Chodyniecki Dariusz, Kapelani wojskowi w dziejach Polski do wybuchu II wojny światowej, ,Saeculum Christianum”, 4 (1997) z. 2, s. 105-153.

Depczyński Wincenty, Parafia Tarnogród, „Nasza Przeszłość”, 37 (1972) s. 125-207.

Derwich Marek, Monastycyzm benedyktyński w średniowiecznej Europie i Polsce. Wybrane problemy, Wrocław 1998.

Dobosz Józef, Monarchia i możni wobec Kościoła $w$ Polsce do początku XIII wieku, Poznań 2002.

Gach Piotr Paweł, Kasaty zakonów na ziemiach dawnej Rzeczypospolitej i Śląsa: 17731914, Lublin 1984. 
Gach Piotr Paweł, Opactwo i sanktuarium Świętego Krzyża w epoce kasat zakonnych (XVIII-XIX wiek), w: Klasztor na Świętym Krzyżu w polskiej kulturze narodowej, red. D. Olszewski, R. Gryz, Kielce 2000, s. 153-169.

Gach Piotr Paweł, Struktura i działalność duszpasterska zakonów męskich na ziemiach dawnej Rzeczypospolitej i Ślaska w latach 1773-1914, Lublin 1999.

Gach Piotr Paweł, Zakonni kapelani wojskowi pod koniec XVIII $i$ w XIX stuleciu, w: Historia duszpasterstwa wojskowego na ziemiach polskich, red. J. Ziółek i inni, Lublin 2004, s. 241-259.

Gach Piotr Paweł, Zakony w diecezji kieleckiej 1805-1914, „Nasza Przeszłość”, 59 (1983) s. $165-213$.

Gacki Józef, Benedyktyński klasztor w Sieciechowie wedtug pism i podań miejscowych, Radom 1872.

Gacki Józef, Benedyktyński klasztor Świętego Krzyża na Łysej Górze, Warszawa 1873.

Gembarzewski Bronisław, Rodowody pułków polskich i oddziałów równorzędnych od r. 1717 do 1831, Warszawa 1925.

Gembarzewski Bronisław, Wojsko Polskie 1815-1830, Warszawa 1903.

Gerlic Henryk, Rewerenda zamiast mniszego habitu - cystersi ślascy po kasacie ich opactw, w: Kasaty klasztorów na obszarze dawnej Rzeczypospolitej Obojga Narodów i na Ślasku na tle procesów sekularyzacyjnych w Europie, t. 2, Kasaty na Ślasku Pruskim i na ziemiach zaboru pruskiego, red. M. Derwich, Wrocław 2014, s. 165-186.

Jaroszek Kazimierz, Inwentarz pozostałości po ostatnim opacie sieciechowskim ks. Wojciechu Biedrzyckim z 1824 r., „Biuletyn Kwartalny Radomskiego Towarzystwa Naukowego", 33 (1998) z. 2-4, s. 125-142.

Juda Maria, Kultura książki w kręgu benedyktynów. Na marginesie dziejów opactwa w Sieciechowie, „Przegląd Informacyjno-Dokumentacyjny”, 2 (2005) s. 45-64.

Kaliszuk Jerzy, Codices deperditi. Średniowieczne rękopisy tacińskie Biblioteki Narodowej utracone w czasie II wojny światowej, t. 1, Dzieje i charakterystyka kolekcji, Wrocław 2016.

Kanior Marian, Polska Kongregacja Benedyktyńska Świętego Krzyża: 1709-1864, Kraków 2000.

Kanior Marian, Końcowe dzieje Polskiej Kongregacji Benedyktyńskiej Św. Krzyża (17721864), „Analecta Cracoviensia”, 14 (1982) s. 557-609.

Kośka Małgorzata, Dekret abpa Franciszka Skarbka-Malczewskiego z 17 IV 1819 r. w sprawie supresji klasztorów w Królestwie Polskim, „Hereditas Monasteriorum”, 8 (2016) s. 367-378.

Kotkowski Stanisław, Seminarium Duchowne w Sandomierzu w latach 1820-1926, Sandomierz 2010.

Kowalczyk Elżbieta, Powracajacy temat Sieciechów. Z problemów organizacji grodowej w Polsce wczesnośredniowiecznej, „Kwartalnik Historii Kultury Materialnej”, 42 (1994) nr 1, s. 69-85.

Kowalska-Kutera Helena, Jaskulska Aldona, Nowakowska Helena, Parafia Podwyższenia Krzyża Świętego, w: Ciepielów dawniej i dziś, red. H. Bednarczyk, H. KowalskaKutera, Sycyna 2001, s. 158-170.

Kraszewski Józef Ignacy, Nekrologi, „Tydzień Polityczny, Naukowy, Literacki i Artystyczny", 19 czerwca 1870, nr 25.

Lechowicz Zbigniew, Filipowicz Paweł, Stan badań nad średniowiecznym opactwem w Sieciechowie, w: Radom: korzenia miasta i regionu, t. 4, Ziemia niczyja - ziemia nieznana. Schylek starożytności i średniowiecze na ziemiach między Wisła a Pilica, red. A. Buko, D. Główka, M. Trzecieski, Warszawa 2013, s. 193-222. 
Mądzik Marek, Z zagadnień polityki wyznaniowej na pograniczu Królestwa Polskiego $w$ okresie międzypowstaniowym (na przykładzie Tarnogrodu), w: Na pograniczu kultur, jezyków i tradycji. Prace ofiarowane profesorowi doktorowi Ryszardowi Szczygłowi w sześćdziesiąta rocznicę urodzin, red. M. Mądzik, A.A. Witusik, Lublin 2004, s. 227-242.

Massalski Adam, Miejsce pokuty i poniżenia. Instytut Księży Zdrożnych (1853-1863) $i$ więzienie rosyjskie (1886-1914) na Świętym Krzyżu, w: Klasztor na Świętym Krzyżu w polskiej kulturze narodowej, red. D. Olszewski, R. Gryz, Kielce 2000, s. 171-192.

Miszczak Danuta, Późnobarokowy kościół pobenedyktyński w Sieciechowie-Opactwie, „Rocznik Muzeum Świętokrzyskiego”, 9 (1975) s. 367-383.

Nowak Edmund, Rys dziejów duszpasterstwa wojskowego w Polsce 968-1831, Warszawa 1932.

Osiński Tomasz, „Propaganda luchowska”. Kulisy konwersji na prawosławie unitów wsi Luchów, Babice, Potok Górny w latach czterdziestych XIX wieku, „Res Historica”, 26 (2008) s. 63-89.

Parafia Maciejowice 1797-2016. Wyniki indeksacji ksiag metrykalnych wykonanej przez Garwolińska Grupę Indeksacyjna, 2017, http://garwolin.org/maciejowice_indeksy (dostęp: 26.09.2018).

Pestka Wojciech, Jak mało... ks. Józef Gacki (1805-1876) - zarys biografii, Radom 2012.

Piątkowski Sebastian, Szymanek Andrzej, Parafia Podwyższenia Krzyża Świętego w Zwoleniu 1425-2002. Monografia historyczna, Zwoleń 2002.

Prejs Roland, Słownik biograficzny zakonników franciszkańskich Królestwa Polskiego po kasacie 1864 r., Poznań 2004.

Reczulski Łukasz, Wójtowa Góra w Sieciechowie, „Acta Universitatis Lodziensis. Folia Archaeologica", 30 (2015) s. 187-205.

Rosowski Witalij, Losy zakonników z klasztorów rzymskokatolickich na Ukrainie Prawobrzeżnej skasowanych $w$ XIX w., w: Kasaty klasztorów na obszarze dawnej Rzeczypospolitej Obojga Narodów i na Ślasku na tle procesów sekularyzacyjnych w Europie, t. 1, Geneza. Kasaty na ziemiach zaborów austriackiego i rosyjskiego, red. M. Derwich, Wrocław 2014, s. 287-301.

Saletra Wojciech, Duchowieństwo obszaru między Wisła a Pilica wobec powstania listopadowego 1830-1831, „Teka Komisji Historycznej”, 8 (2011) s. 141-160.

Skała Agata, Kościót Podwyższenia Krzyża Świętego w Zwoleniu, Lublin 1998.

Stalmach Krzysztof, Administracja lasów suprymowanych i duchownych województwa sandomierskiego w latach 1818-1832, „Ziemia Kozienicka”, 24-25 (2011) s. 5-22.

Stalmach Krzysztof, Kasata zakonu benedyktynów sieciechowskich w 1819 r. i zarzad ich majatku w okresie konstytucyjnym, mps, praca doktorska obroniona w 2008 r. na Katolickim Uniwersytecie Lubelskim.

Stanaszek Bogdan, Nowakowski Ryszard, Tylec Piotr, Słownik biograficzny księży diecezji sandomierskiej XIX-XX w., t. 1-3, Sandomierz 2014-2017.

Stępień Robert, Pokasacyjne losy $i$ obecny stan zachowania archiwaliów klasztoru Benedyktynów z Sieciechowa, „Res Historica”, 45 (2018) s. 131-153.

Stępień Robert, Spory o granice posiadłości ziemskich benedyktynów z Sieciechowa, „Słupskie Studia Historyczne”, 18 (2012) s. 61-70.

Stopniak Franciszek, Dzieje Kapituły Zamojskiej, Lublin 1962.

Szczepańska Grażyna, Kalendarium Dęblina, Dęblin 2014.

Szymanek Andrzej, Pożyczka benedyktynów z Sieciechowa dla Żydów ze Zwolenia i Janowca, 1685 r., „Notatnik Janowiecki”, 16 (2009) s. 355-363. 
Śladkowski Wiesław, Ostatni bastion powstania listopadowego, w: Zamość: z przeszłości twierdzy i miasta, red. A. Koprukowniak, A.A. Witusik, W. Ćwik, Lublin 1980, s. 164-181.

Wąsowicz Teresa, Topografia wczesnośredniowiecznego Sieciechowa, „Przegląd Historyczny”, 50 (1959) z. 3, s. 569-581.

Wimmer Jan, Historia piechoty polskiej do roku 1864, Warszawa 1978.

Wiśniewski Jan, Dekanat iłżecki, Radom 1912.

Wiśniewski Jan, Dekanat kozienicki, Radom 1913.

Wiśniewski Jan, Dekanat opatowski, Radom 1907.

Wiśniewski Jan, Dekanat radomski, Radom 1911.

Wiśniewski Jan, Dekanat sandomierski, Radom 1915.

Wiśniewski Krzysztof, Kościół św. Piotra i Pawła Apostołów oraz inne zabudowania jezuickie $i$ benedyktyńskie $w$ Puttusku (inwentarze z lat 1781-1882 oraz dokumentacja fotograficzna), „Hereditas Monasteriorum”, 5 (2014) s. 107-161.

Wiśniewski Krzysztof, Szkolnictwo benedyktyńskie w Pultusku w latach 1781-1833, „Nasza Przeszłość”, 117 (2012) s. 205-214.

Wiśniewski Krzysztof, Z dziejów konwentu benedyktynów w Pułtusku w latach 1781-1864, w: Puttusk. Studia i materiaty z dziejów miasta i regionu, t. 6, red. J. Szczepański, Pułtusk 2005, s. 111-138.

Wiśniowski Eugeniusz, Z dziejów opactwa benedyktynów w Sieciechowie (XIII-XVI w.), „Roczniki Humanistyczne”, 7 (1958) z. 2, s. 23-120.

Wiśniowski Eugeniusz, Najstarszy dokument benedyktynów sieciechowskich (1252), „Studia Źródłoznawcze”, 4 (1959) s. 57-73.

Wykaz duchownych świeckich zmartych w ciagu roku 1856 w Królestwie Polskim, „Pamiętnik Religijno-Moralny”, 33 (1857) z. 7, s. 80-84.

Zawadzki Wojciech, Losy franciszkanów w Prusach Zachodnich w okresie kasat ich klasztorów, „Hereditas Monasteriorum”, 2 (2013) s. 95-107.

Ziółek Ewa Małgorzata, Duszpasterstwo w wojsku Księstwa Warszawskiego, Królestwa Polskiego i po powstaniu listopadowym, w: Historia duszpasterstwa wojskowego na ziemiach polskich, red. J. Ziółek i inni, Lublin 2004, s. 173-197.

Zdon Wojciech, Dydaktyka zbawienia na sklepieniach pobenedyktyńskiego kościota $w$ opactwie sieciechowskim, „Arteria. Rocznik Katedry Sztuki Wydziału Nauczycielskiego Politechniki Radomskiej”, 6 (2008) s. 33-38.

Zdon Wojciech, Świątynia jako miejsce na granicy przemijania i wiecznej szczęśliwości, czyli o znaczeniu campanulli $w$ architekturze kościoła opackiego $w$ Sieciechowie, w: Obraz i przyroda, red. M. Mazurczak, J. Patyra, M. Żak, Lublin 2005, s. 549-559. 


\title{
LOSY BENEDYKTYNÓW SIECIECHOWSKICH PO KASACIE OPACTWA W 1819 ROKU
}

\begin{abstract}
Streszczenie
Artykuł omawia losy ostatnich zakonników klasztoru benedyktynów w Sieciechowie po kasacie opactwa w 1819 r. Podstawowym materiałem źródłowym dla badań w tym zakresie były teczki personalne duchowieństwa oraz akta konduit i stanu służby kapłanów przechowywane w zasobie Archiwum Diecezjalnego w Sandomierzu. Rekonstrukcja losów ostatnich benedyktynów sieciechowskich dowiodła, że większość z nich po supresji opactwa podjęła pracę duszpasterską w ośrodkach parafialnych, położonych na terenie kilku ówcześnie istniejących diecezji. Trzech byłych zakonników zakończyło swój żywot jako administratorzy kościoła na Łysej Górze. Artykuł w swym założeniu stanowi punkt wyjścia do dalszych badań nad dziejami benedyktynów z Sieciechowa, jak też szerzej nad problematyką losów duchowieństwa zakonnego w okresie XIX-wiecznych kasat klasztornych.

Słowa kluczowe: benedyktyni; Sieciechów; klasztor; kasata
\end{abstract}

\section{THE HISTORY OF THE BENEDICTINES FROM SIECIECHÓW AFTER THE DISSOLUTION OF THE MONASTERY IN 1819}

\begin{abstract}
Summary
The article discusses the history of the last monks from the Sieciechów Benedictine monastery after its dissolution in 1819 . The basic source material for this research included personal files of the monks and secular clergy, the records concerning the work and death of the priests held in the Diocesan Archive in Sandomierz. The reconstruction of the history of the last Benedictines from Sieciechów shows that following the suppression of the monastery, most of them conducted pastoral work in the parishes situated in a few dioceses which existed at the time. The last monks died as administrators of the church in Łysa Góra. The following article constitutes a starting point for further research on the history of the Benedictines from Sieciechów as well as all monks in the period of the 19th-century dissolution of monasteries.
\end{abstract}

Keywords: the Benedictines; Sieciechów; a monastery; dissolution; a personal history 